\title{
A influência dos elementos de informação do inquérito policial na fundamentação da sentença penal condenatória: uma análise das sentenças prolatadas pelas varas criminais de Maceió/AL
}

The influence of elements of information of police investigation on the motivation of condemnatory criminal

sentence: an analysis of the decisions pronounced by criminal courts of Maceió/AL

\section{André Rocha Sampaio ${ }^{1}$}

Centro Universitário Tiradentes - Maceió, Alagoas, Brasil andrerochasampaio@gmail.com

http://lattes.cnpq.br/0645556530168637

http://orcid.org/0000-0002-6288-5487

Marcelo Herval Macêdo Ribeiro ${ }^{2}$

Universidade Federal de Alagoas - Maceió, Alagoas, Brasil marcelohervalribeiro@hotmail.com http://lattes.cnpq.br/6062945502758177 http://orcid.org/0000-0001-8181-6922

1 Doutor em Ciências Criminais pela Pontifícia Universidade Católica do Rio Grande do Sul (PUCRS) (2016), Mestre em Direito pela Universidade Federal de Alagoas (UFAL) (2009), pós-graduado em Ciências Criminais pela ESAMC (2006), graduado em Direito pela Universidade Federal de Alagoas (2003). Professor da disciplina Direito Penal, Direito Processual Penal e Criminologia e Advogado. Professor de pós-graduações no Estado. Coordenador do Grupo de Pesquisa Biopolítica e Processo penal. Membro do Instituto Brasileiro de Processo Penal.

2 Mestrando em Direito Público pela Universidade Federal de Alagoas (UFAL), vinculado à linha de pesquisa "Crimes, punições e direitos Violados: das normas penais e processuais às políticas criminais". Graduado em Direito pelo Centro Universitário Tiradentes. Advogado. Vice-presidente da Comissão de Estudos Criminais da OAB/ AL. Coordenador adjunto do Grupo de Estudos em Ciências Criminais e Direitos Humanos do IBCCRIM/AL. Membro do Grupo de Pesquisa Biopolítica e Processo Penal. Membro do Fórum Popular de Segurança Pública de Alagoas (FPSP/AL). 


\section{Amanda Assis Ferreira ${ }^{3}$}

Centro Universitário Tiradentes - Maceió, Alagoas, Brasil amandaassisfz@hotmail.com

http://lattes.cnpq.br/3900698855874444

http://orcid.org/0000-0002-3053-2986

Resumo: O presente artigo propõe apresentar a frequência de utilização do inquérito policial enquanto parte da fundamentação de sentenças judiciais provenientes das Varas Criminais Residuais da cidade de Maceió - Alagoas, a fim de desvelar o funcionamento inquisitório e, portanto, antidemocrático, do devido processo penal. Partindo de uma pergunta-problema de cariz empírico, qual seja, "o inquérito policial é utilizado na fundamentação de sentenças judiciais?", foram adotadas técnicas metodológicas também empíricas: a análise de fluxo do sistema de justiça criminal e a utilização de um instrumento quali-quanti. Para tanto, o desenvolvimento da pesquisa em questão fora dividido em três principais momentos, a saber: a delimitação do objeto, a coleta de dados e, por fim, a análise dos dados coletados. Após tal investigação, restou demonstrada a efetiva utilização dos elementos informativos na fundamentação das sentenças, visto que em $80,6 \%$ dos casos, (correspondente a 369 processos) o magistrado se utilizou expressamente de algum elemento informativo produzido durante as investigações preliminares, sendo, deste total, cerca de $91 \%$ (336) dos processos referentes a sentenças condenatórias. Assim sendo, conflui-se para a confirmação dos problemas que permeiam o art. 155 do Código de Processo Penal, quando inseridos num sistema de teor essencialmente inquisitório.

Palavras-Chave: Inquérito policial; sentenças; fundamentação; inquisitório; elementos de informação.

ABSTRACT: This article proposes to present the frequency of use of the police investigation as part of the motivation of judicial decisions coming

3 Graduanda em Direito pelo Centro Universitário Tiradentes UNIT - AL. Membro do Grupo de Pesquisa Biopolítica e Processo Penal. 
from the Residual Criminal Courts of Maceió city - Alagoas, in order to unveil the inquisitory and therefore undemocratic functioning of the due criminal process. Starting from an empirical problem question, "is the police investigation used in the motivation of court sentences?" methodological techniques were also adopted: the flow analysis of the criminal justice system and the use of a qualitative and quantitative instrument. To this intent, the development of the research in question was divided into three main moments, namely: the delimitation of the object, the data collection and, finally, the analysis of the collected data. After this investigation, the effective use of the informative elements in the reasoning of the sentences was demonstrated, since in $80.6 \%$ of the cases (corresponding to 369 cases) the magistrate expressly used some informative element produced during the preliminary investigations, corresponding, of this total, about 91\% (336) of the cases relating to condemnatory judgments. Thus, it converges to the confirmation of the problems that permeate the art. 155 of the Code of Criminal Procedure, when inserted in an essentially inquisitive system.

KeYwords: Police investigation; sentences; reasoning; inquisitive; elements of information.

SUMÁRIO: Introdução; 1. Nuances e aspectos lúgubres do inquérito policial; 1.1. A imperiosa necessidade de repetição dos atos de prova repetíveis e a problemática em torno da mera ratificação em juízo; 2. Mapeamento da influência dos elementos de investigação preliminar na fundamentação das sentenças criminais publicadas em 2016 no estado de alagoas; 2.1. Notas metodológicas; 2.2. Dificuldades empíricas. 2.3. Resultados obtidos; 3. A criptomotivação a serviço de valores autoritários. Considerações Finais; Referências.

\section{INTRODUÇÃO}

O inquérito policial é um procedimento de natureza administrativa cuja finalidade precípua dirige-se à obtenção de informações relativamente a um suposto fato criminoso, objetivando, em última análise, consubstanciar a opinio delicti do órgão acusador e a eventual propositura da exordial acusatória. Embora na sistemática processual penal brasileira este procedimento preliminar se classifique como dispensável, porquanto 
seja possível que a ação se inicie a despeito da inexistência de quaisquer diligências policiais - bastando, para tanto, que as informações concernentes à materialidade do delito e à suposta autoria delitiva tenham sido, por outro(s) modo(s), obtidas, calha observar que, na prática forense, $o$ inquérito policial é instrumento utilizado em parcela inequivocamente majoritária de ações penais, de tal sorte que a dispensabilidade acima referida não é habitualmente percebida.

A reforma processual penal de 2008 , levada a cabo por meio das Leis $n^{0} 11.690 / 2008$ e $n^{0} 11.698 / 2008$, conferiu nova redação ao anterior artigo 157 do Código de Processo Penal, passando a estatuir - doravante em seu artigo 155 - , que "o juiz formará sua convicção pela livre apreciação da prova produzida em contraditório judicial, não podendo fundamentar sua decisão exclusivamente nos elementos informativos colhidos na investigação, ressalvadas as provas cautelares, não repetíveis e antecipadas".

Significa dizer que o legislador, reconhecendo as imanentes deficiências presentes nesta fase preliminar, em especial a precarização do contraditório e da ampla defesa, vedou aos magistrados que se utilizassem, como mecanismos exclusivos a fundamentar uma eventual decisão condenatória, os elementos de investigação coligidos no inquérito policial.

Não obstante a referida vedação, o que se tem observado corriqueiramente nas Varas Criminais de Maceió/AL é a frequente presença dos elementos de informação obtidos durante a fase pré-processual como fundamentos jurídicos utilizados para legitimar sentenças judiciais, notadamente condenatórias, evidenciando, com efeito, uma violação às limitações acima mencionadas. Deveras, o inquérito policial ultrapassa não raras vezes suas funções declaradamente oficiais, influenciando, por conseguinte, o convencimento do magistrado a respeito de um suposto fato criminoso submetido à exame.

Tal expediente, sublinhe-se, apresenta-se inquestionavelmente problemático, na medida em que, ao ter contato prévio com os atos de investigação, a tese acusatória se adere à cognição do julgador, fazendo com que ele decida antes, e depois, apenas busque elementos que tencionem a fundamentar um convencimento já formado. Esse panorama resta francamente favorável ao surgimento de quadros 
mentais paranoicos, oportunizando, por conseguinte, a superveniência de fenômenos como o efeito perseverança ${ }^{4}$ e o primado das hipóteses sobre os fatos ${ }^{5}$.

Muito recentemente entrou em vigor a Lei 13.964, que trouxe, ao menos no plano legislativo, importantes modificações que afetam diretamente a relação das peças de informação com o julgamento, tal qual a extração física dos autos, mantendo apenas os atos irrepetíveis, cautelares ou antecipados, e a instituição do juiz de garantias, cujo objetivo seria o de preservar a virgindade cognitiva do juiz do processo.

Diante desse contexto, a pesquisa aqui exposta se propõe a investigar empiricamente o grau de influência dos elementos de informação coligidos no inquérito policial à fundamentação de decisões criminais condenatórias. Por intermédio de um instrumento de análise quantitativo-qualitativo, aplicado em face de 458 processos julgados em 2016 na comarca de Maceió/AL, objetivou-se responder ao seguinte questionamento: "o inquérito policial é utilizado na fundamentação de sentenças judiciais?”.

A partir da experiência profissional e acadêmica dos pesquisadores face às Varas Criminais supra aludidas, ventilou-se a hipótese de que um índice superior a 90\% das sentenças penais condenatórias utiliza-se, direta ou indiretamente, dos elementos informativos oriundos da fase investigativa, muitos dos quais não são repetidos no curso do processo penal, de tal sorte que o convencimento judicial se consubstancia fundamentalmente a partir de elementos produzidos em um expediente inquisitório, discricionário e, via de regra, unilateral - sem a observância, portanto, das garantias constitutivas de um processo penal acusatório e legitimamente democrático.

Calha salientar que eventuais afetações da Lei 13.964 não serão, por óbvio, analisadas, visto se tratar de pesquisa realizada bem antes de sua entrada em vigor.

4 SCHUNEMANN, Bern. O juiz como um terceiro manipulado no processo penal? Uma confirmação empírica dos efeitos perseverança e aliança. In: GRECO, Luís. Estudos de direito penal, direito processual penal e filosofia do direito. São Paulo: Marcial Pons, 2013, p. 208-219.

5 CORDERO, Franco. Guida all aprocedurapenale. Torino: UTET, 1986, p. 52-53. 


\section{NuANCES E ASPECtos LÚgUbRes do INQUÉRITO POLICIAL}

A fase preliminar, a primeira etapa do processo penal - teoricamente dispensável, mas quase sempre presente -, é ainda sustentada por bases forjadas na década de quarenta, em uma estrutura hegemonicamente punitivista e afastada da maior parte das exigências presentes na contemporaneidade, principalmente a imposição de limites a eventuais excessos do poder do Estado.

Ainda hoje, quando um delito é cometido, em suma, o Estado por intermédio da polícia civil - deve buscar elementos informativos iniciais acerca da autoria e materialidade sobre este delito. É o inquérito policial o procedimento administrativo preliminar predominantemente utilizado nesta primeira etapa da persecução criminal, estruturando toda a investigação preliminar. Este procedimento foi mantido pelo Código de Processo Penal de 1941, posicionado na fase pré-processual, sendo o gênero do qual são espécies o inquérito policial, as comissões parlamentes de inquérito e sindicâncias, exemplificativamente ${ }^{6}$.

Esta forma de investigação é composta por uma série de diligências que têm como objetivo obter elementos de informação para que o titular da ação penal possa propô-la contra o suposto infrator.

Existem outros modelos para esta investigação preliminar que se classificam de acordo com a preponderância do sujeito destinatário da notitia criminis e a direção dessa fase. Nereu Giacomolli, em relação ao tema, alude sobre a existência de três modelos: o direcionado pelo magistrado, pelo promotor de justiça e pela autoridade policial.

Sobre estes modelos, é interessante perscrutar a visão de Giacomolli, que reputa que nenhum dos três modelos substitui a necessidade da existência da fase processual. Por isso, não é vantajoso atribuir a nenhum deles a posição de superioridade, pois todos os modelos possuem pontos negativos e positivos, e o principal é que se ofereça um equilíbrio entre eficácia persecutória e garantias dos

6 LOPES JUNIOR, Aury. Direito processual penal. 15ª ed. São Paulo: Saraiva, 2018, p. 119. 
direitos fundamentais, independentemente do sujeito encarregado de dirigir a fase preliminar ${ }^{7}$.

Demonstra ainda que não é este ou aquele modelo o ideal, mas o seu regramento, visto que pouco adiantaria substituir o dirigente da fase preliminar na atual situação caótica e de abandono da persecutio criminis no Brasil. A substituição da autoridade policial na coordenação da investigação criminal representaria uma fissura no pacto democrático, o aumento da inquisitorialidade ${ }^{8}$.

Destarte, como determina o artigo $4^{\circ}$ do CPP, o inquérito no Brasil é realizado pela polícia judiciária (que se diferencia da polícia preventiva, na medida em que esta resta configurada como o policiamento ostensivo realizado pelas Polícias Militares). Como o âmbito da pesquisa a seguir apresentada engloba sentenças proferidas pelas Varas criminais residuais da cidade de Maceió, a polícia responsável neste caso é a Polícia Civil, seguindo a tendência da limitação dos âmbitos estaduais e federais, apesar de não haver proibição de uma eventual troca de competência entre as esferas. ${ }^{9}$

Ainda em relação às funções basilares do inquérito, tem-se que este deve fornecer elementos fáticos para a base acusatória. Porém, é também um importante filtro para que se evitem acusações infundadas, obviamente desarrazoadas e sem indícios de autoria, visto que o processo penal é uma pena em si mesmo, na medida em que se faz impossível processar sem punir e punir sem processar, pois o investigado sofre os estigmas sociais e jurídicos e ainda consequências psicológicas de um estado prolongado de ânsia, em saber que está sendo investigado ou processado $^{10}$. Em termos gerais, pensa-se que o fundamento da investigação

7 GIACOMOLLI, Nereu José. A fase preliminar do processo penal: Crises, misérias e novas metodologias investigatórias. Edição. Rio de Janeiro: Lumen Juris, 2011. p. 26.

8 GIACOMOLLI, Nereu José. A fase preliminar do processo penal: Crises, misérias e novas metodologias investigatórias. Edição. Rio de Janeiro: Lumen Juris, 2011. p. 27.

9 LOPES JUNIOR, Aury. Direito processual penal. 15 ${ }^{\text {a }}$ ed. São Paulo: Saraiva, 2018, p. 122.

10 LOPES JR., Aury. GLOECKNER, Ricardo Jacobsen. Investigação Preliminar no Processo Penal. ed. 5. São Paulo: Saraiva, 2013, p. 112-113 
preliminar é evitar acusações ilegítimas, pois se o seu objetivo fosse apenas obter elementos probatórios, tornar-se-ia supérflua, tendo em vista que isso poderia, teoricamente, ser realizado diretamente na fase processual, economizando tempo da persecução penal ${ }^{11}$.

Em que pese a distopia entre a prática e a realidade, a função do inquérito é ambivalente, visto que, ao passo que deve viabilizar, ao mesmo tempo deve obstar o exercício da ação penal ${ }^{12}$, basculando a persecução criminal em prol de ideais de justiça apenas contingencialmente alcançáveis. Conforme Scarance Fernandes, trata-se da maior expressão de uma importante garantia, que tem como função evitar que alguém seja acusado sem estar verificada a existência de indícios razoáveis apontando-o como autor de um ilícito penal. ${ }^{13}$

Apesar de o Código de Processo Penal ter passado por uma considerável reforma no ano de 2008, estas mudanças não lograram êxito em atingir resultados necessários a ponto de alterar os rumos do processo penal, dado que não contemplou e ainda não contempla a modernização necessária para a segurança e confiabilidade do processo, baseadas num modelo acusatório que formem alicerces para uma investigação séria e que possa de fato oferecer provas da materialidade e indícios de autoria para que o titular da ação penal disponha de elementos seguramente válidos para promovê-la.

É desta forma que todas as particularidades do inquérito se amoldam no Código de Processo Penal, desde sua instauração até o relatório, ato que o encerra, elaborado por quem o preside.

Em que pese existirem outras formas de instauração do inquérito, tem-se a chamada instauração compulsória como o meio mais comum e utilizado. Quando alguém é pego em situação de flagrante, deve-se

11 VASCONCELLOS, Vinicius Gomes de. Fundamento e função do processo penal: a centralidade do juízo oral e sua relação com as demais fases da persecução penal para a limitação do poder punitivo. Revista Eletrônica de Direito Processual - REDP, Rio de Janeiro, v. 19, n. 2, p. 229-260, ago./2018.

12 GIACOMOLLI, Nereu José. A fase preliminar do processo penal: Crises, misérias e novas metodologias investigatórias. Edição. Rio de Janeiro: Lumen Juris, 2011. p. 50-51.

13 FERNANDES, Antonio Scarance. Teoria Geral do Procedimento e O Procedimento no Processo Penal. São Paulo: RT, 2005. p. 75 
efetuar a prisão e fazer cessar a atividade criminosa, sendo lavrado o auto respectivo, considera-se instaurado o inquérito policial ${ }^{14}$.

Interessante particularidade do inquérito policial diz respeito ao sigilo, característica que rege uma de suas principais diferenças em relação ao processo penal em si. Em que pese a distopia entre a teoria e a realidade, o sigilo tem a função de preservar o indiciado e de assegurar a eficácia da investigação, evitando hostilidades sociais decorrentes da estigmatização que a publicidade do inquérito pode trazer ${ }^{15}$.

Em relação à norma que impõe sigilo, Elmir Duclerc, em análise ao artigo 20 do CPP, que versa sobre a forma escrita do inquérito (visto que a regra geral supostamente é a publicidade), expõe que o legislador infraconstitucional relaciona a necessidade de sigilo nas investigações apenas à preservação da própria investigação ou de algum outro interesse social relevante, a critério da autoridade policial, e que é assim que, lamentavelmente, a maioria da doutrina e da jurisprudência pátrias se posicionam ${ }^{16}$.

Desta forma, quando o fim deste sigilo for útil aos propósitos da própria investigação, ou seja, direcionado ao indiciado e seu defensor, tem-se uma presunção de que esses são os principais interessados em saber de antemão o que está sendo investigado para, à luz dessas informações, traçar desde logo alguma estratégia de defesa ou até mesmo colocar obstáculos, plantar informações inverídicas, enfim, tudo fazer para que o trabalho da autoridade policial, de alguma forma, não seja bem sucedida. Entende-se, deste modo, não haver maiores problemas em a autoridade policial lançar mão da regra do art. 20 do $\mathrm{CPP}^{17}$, mas, sempre

14 NICOLITT, André. Manual de processo penal. 8. ed. Belo Horizente: DPlácido, 2019. p. 223-225. No estudo empírico que deu origem a esta pesquisa, percebeu-se que a grande maioria das persecuções processuais penais se iniciam com um flagrante delito, conforme posterior exposição de dados coletados. Os motivos para tal não são determinantes, mas perpassam o costume ostensivo das polícias militares, sobretudo em áreas específicas das cidades.

NICOLITT, André. Manual de processo penal. 8. ed. Belo Horizente: D”plácido, 2019. p. 215

DUCLERC, Elmir. Direito Processual Penal. Rio de Janeiro: Lumen Juris, 2007. p. 88-89

17 Art. 20. A autoridade assegurará no inquérito o sigilo necessário à elucidação do fato ou exigido pelo interesse da sociedade. 
que isso for necessário, o sigilo deve ser decretado através de despacho fundamentado, vez que, como já dito e reiterado pela Lei 13.245/2016, a regra é a publicidade ${ }^{18}$.

Em que pese às mudanças trazidas pela Lei 13.245/2016, que alterou o art. $7^{\circ}$ do Estatuto da Ordem dos Advogados do Brasil (Lei 8.906/94), reforçando as prerrogativas do advogado no acompanhamento do inquérito policial e possibilitando instrumentos mais efetivos para que a sua intervenção durante essa fase seja mais eficaz, ainda subsistem problemas em relação à capacidade financeira que as pessoas que geralmente são pegas em flagrante possuem de constituir advogados, visto que a grande maioria delas pertence à classe baixa ${ }^{19}$.

A Defensoria Pública, por sua vez, ainda que de exorbitante importância para defesa de pessoas hipossuficientes, não tem como suprir a tamanha demanda de flagrantes que ocorrem diariamente, acompanhando todos os flagranteados em seus depoimentos na fase inquisitorial, restando, então, declarações desacompanhadas de defesa técnica ${ }^{20}$.

Em relação à presença ou não do contraditório e direito de defesa nesta fase, Aury Lopes Jr. e Ricardo Gloeckner acreditam que, em sentido estrito, não pode existir contraditório pleno no inquérito visto não existir uma relação jurídico-processual instaurada, não estando, desta forma, presente a estrutura dialética que caracteriza o processo, não havendo então a possibilidade do exercício de uma pretensão acusatória. Contudo, tem-se também a ideia de que esse direito à informação - importante faceta do contraditório - adquire relevância na medida em que através dele seja exercida a defesa ${ }^{21}$.

18 DUCLERC, Elmir. Direito Processual Penal. Rio de Janeiro: Lumen Juris, 2007. p. 90

19 RAMOS, Silvia; MUSUMECI, Leonarda. "Elemento suspeito”. Abordagem policial e discriminação na cidade do Rio de Janeiro. Boletim Segurança e Cidadania, n. 8, novembro de 2004.

20 Conforme estudo realizado pelo IPEA, a Defensoria Pública está presente apenas em $28 \%$ das comarcas. Nesse sentido, cf. Instituto de Pesquisa Econômica Aplicada - IPEA. Mapa da Defensoria Pública no Brasil. Disponível em: <http://www.ipea.gov.br/sites/mapadefensoria/defensoresnosestados>. Acesso em 23 de janeiro de 2019>.

21 LOPES JR., Aury. GLOECKNER, Ricardo Jacobsen. Investigação Preliminar no Processo Penal. ed. 5. São Paulo: Saraiva, 2013, p. 468 
Em relação ao direito de defesa, é preciso ponderar seus limites de atuação nesta fase, pois, se exercido sem uma limitação, retiraria a característica inerente à própria finalidade da investigação preliminar e a tornaria muito semelhante ao processo em si, não restando diferenciação que justificasse, então, a existência de uma separação entre as fases e nem a potencial confiabilidade dada ao resultado da segunda fase da persecução penal ${ }^{22}$, o que relegaria o juiz ao papel de mero homologador das atividades realizadas pré-processualmente.

Aury Lopes Jr. individualiza particularidades de cada tipo de ato. Sobre os atos de investigação, tem-se que eles não se referem a uma afirmação, mas a uma hipótese, servindo então para formar um juízo de probabilidade e não de certeza e para a formação da opinio delicti do acusador. Ademais, não estão destinados à sentença, mas a demonstrar a probabilidade do fumus commissi delicti para justificar o processo (recebimento da ação penal) ou o não processo (arquivamento) ${ }^{23}$.

Os atos de prova, por sua vez, estão a serviço do processo e integram o processo penal. Estão direcionados a convencer o juiz do valor verdade de uma afirmação, formando um juízo de certeza que servirá para a produção da sentença. Para isso, esses atos probatórios exigem estrita observância à publicidade, contradição e imediação e são praticados ante o juiz que julgará o processo. Depreende-se, portanto, que é nesta fase que a valoração jurídica deve ser baseada, prevalecendo sobre a fase anterior.

É neste contexto de valoração de provas que será trazido o ponto crucial da presente pesquisa, em que o art. 155 do $\mathrm{CPP}^{24}$ abre notável fissura em prol da utilização desproporcional dos dois tipos de atos como se sinônimos fossem, "ou seja, estamos diante de uma forma

22 LOPES JR., Aury. GLOECKNER, Ricardo Jacobsen. Investigação Preliminar no Processo Penal. ed. 5. São Paulo: Saraiva, 2013 p. 470

23 LOPES JUNIOR, Aury. Direito processual penal. 15 ${ }^{\mathrm{a}}$ ed. São Paulo: Saraiva, 2018, p. 158-159

24 Art. 155. O juiz formará sua convicção pela livre apreciação da prova produzida em contraditório judicial, não podendo fundamentar sua decisão exclusivamente nos elementos informativos colhidos na investigação, ressalvadas as provas cautelares, não repetíveis e antecipadas. 
cínica de relativizar as garantias processuais, quase sempre em nome de um conceito etéreo de verdade real" 25 .

\subsection{A IMPERIOSA NECESSIDADE DE REPETIÇÃO DOS ATOS DE PROVA REPETÍVEIS E A PROBLEMÁTICA EM TORNO DA MERA RATIFICAÇÃO EM JUÍZO.}

Consoante acima observado, somente os atos de prova - vale dizer, aqueles produzidos durante a fase jurisdicional, em estrita observância às garantias constitutivas do devido processo legal - é que podem ser objeto de valoração relativamente ao caso penal sob judice. De fato, os elementos meramente informativos, obtidos no curso das investigações preliminares a partir de atos discricionários e inquisitórios de investigação, possuem apenas o condão de subsidiar a opinião delitiva do órgão acusador (em regra, Ministério Público) acerca de um fato aparentemente criminoso, não servindo como mecanismos legítimos à consubstanciação condenatória ${ }^{26}$ quanto à materialidade e autoria delitivas.

Nessa toada, a doutrina processual de viés mais crítico, conferindo interpretação à norma positivada no artigo 155 do Código de Processo Penal mediante exegese compatível aos ditames de um sistema processual acusatório, estabeleceu distinção ontológica entre os atos de prova repetíveis e não repetíveis. Segunda essa intelecção, tem-se que as provas repetíveis diriam respeito àqueles elementos cuja repetição, na fase processual, não prejudicaria a incolumidade do conteúdo anteriormente produzido no curso da fase preliminar. Estariam inseridas nessa categoria os depoimentos testemunhais (via de regra), acareações e reconhecimentos, os

25 DUCLERC, Elmir. Direito Processual Penal. Rio de Janeiro: Lumen Juris, 2007. p. 93

26 Frise-se que malgrado não possam subsidiar - exclusivamente, nos termos do artigo 155 do CPP - uma decisão condenatória, nada obsta que os elementos informativos repetíveis, mesmo inquisitoriais, sirvam como elementos aptos à absolvição. Nesse sentido, Aury Lopes Jr afirma, com supedâneo nos ensinamentos de Cláudio Tovo, que "as provas repetíveis ou renováveis, enquanto inquisitoriais, têm valor meramente informativo - os chamados atos de investigação - , não podendo servir de base ou sequer apoiar subsidiariamente o veredicto condenatório, mas nada impede que sirvam de alicerce ao veredicto absolutório.” LOPES JUNIOR, Aury. Direito processual penal. $15^{\mathrm{a}}$ ed. São Paulo: Saraiva, 2018, p. 160, grifos nossos. 
quais somente gozariam do status de prova e, portanto, se apresentariam como elementos aptos à valoração judicial, após a necessária submissão ao contraditório e à ampla defesa ${ }^{27}$.

Com efeito, a legitimidade da valoração conferida a essa modalidade de elemento probatório impende que sua produção tenha rigorosamente ocorrido na fase processual. Nesse sentido, todos os elementos informativos "reunidos na fase pré-processual [...] devem ser repetidos na fase processual, leia-se, colhidos perante o magistrado, numa instrução dialética, sob o crivo do contraditório e ampla defesa" ${ }^{28}$. Assim, se uma testemunha houver prestado depoimento durante a fase investigativa preliminar (isto é, no inquérito policial), a validade axiológica deste elemento relativamente à influência sobre o convencimento do julgador condicionar-se-á à repetição do testemunho no curso do processo, em audiência judicial pública, haja vista que - repise-se - durante o inquérito não se verificam com mesmo rigor as garantias que constituem o devido processo legal, notadamente o contraditório e a ampla defesa.

Por outro lado, os atos de prova irrepetíveis correspondem àqueles aos quais a própria natureza do ato não permite que haja repetição durante a fase processual, devendo, portanto, sua realização ocorrer "no momento do seu descobrimento, sob pena de perecimento ou impossibilidade de posterior análise" 29 . Integram esta categoria as provas técnicas - por exemplo, os laudos periciais - bem como aqueles depoimentos cuja extração se afigura premente e impreterível. São os casos de testemunhas senis ou convalescentes, assim como as testemunhas que por algum motivo precisarem ausentar-se. Nessas hipóteses, preleciona a doutrina crítica, com fulcro na disposição constante no artigo 225 do Código de Processo Penal ${ }^{30}$, que deverá ser procedido à instauração de um incidente

27 TÁVORA, Nestor; ALENCAR, Rosmar.Curso de direito processual penal.13. ed.rev. e atual. Salvador: Ed. JusPodivm. 2018, p. 161.

28 TÁVORA, Nestor; ALENCAR, Rosmar. Curso de direito processual penal. 13. ed.rev. e atual. Salvador: Ed. JusPodivm. 2018, p. 160.

29 LOPES JUNIOR, Aury. Direito processual penal. 15 ${ }^{\mathrm{a}}$ ed. São Paulo: Saraiva, 2018, p. 162.

30 Art. 225. Se qualquer testemunha houver de ausentar-se, ou, por enfermidade ou por velhice, inspirar receio de que ao tempo da instrução criminal já 
de produção antecipada de provas, cuja eficácia será “condicionada aos requisitos mínimos de jurisdicionalidade, contraditório, possibilidade de defesa e fiel reprodução na fase processual" ${ }^{31}$.

Questão assaz problemática, no entanto, diz respeito à mera ratificação dos atos de prova repetíveis. Como se afirmou inicialmente, tratando-se de ato de prova cuja repetição seja obrigatória - v.g, nos casos de testemunhas não enfermas ou nas hipóteses de reconhecimento de pessoas ou coisas - ainda que o ato tenha sido produzido durante o inquérito policial, sua repetição se afigura como requisito de validade à utilização do conteúdo em eventual sentença condenatória.

Todavia, o que comumente se observa na práxis forense é a simples ratificação do depoimento previamente colhido, isto é, a mera leitura do testemunho anteriormente realizado, quer seja pelo juiz quer seja pelas partes. Nessas hipóteses, tem-se que as garantias inerentes à produção da prova no processo - especialmente a oralidade, a imediação e a contradição - quedam-se largamente infirmadas e, não raras vezes, inteiramente excluídas.

Com efeito, muitos julgadores, escudando-se no fato de que o judiciário se encontra abarrotado de processos criminais pendentes, utilizam-se do subterfúgio da ratificação a fim de simplificar o procedimento que, em rigor, deveria ser observado. Não obstante, como apontado por Aury Lopes Jr., esse expediente não pode ser compreendido como efetiva repetição. Conforme preleciona o autor,

não exista, o juiz poderá, de ofício ou a requerimento de qualquer das partes, tomar-lhe antecipadamente o depoimento.

31 A propósito dos elementos probatórios irrepetíveis, Andé Rocha Sampaio discorre que estas modalidades "deverão permanecer na fase processual, logo sua constituição em fase preliminar requer certos cuidados. Em obediência às garantias do contraditório e ampla defesa, é fundamental que a defesa do investigado seja devidamente intimada de data, hora e local da realização do ato por natureza irrepetível para, querendo, estar presente para exercer seu direito de informação e possibilidade de reação. Em não havendo defensor constituído ou sequer investigado definido, deve a defensoria pública estar presente obrigatoriamente." Nesse sentido, SAMPAIO, André Rocha.. A onipresença processual dos atos de investigação como sintoma biopolítico. 2015. Tese (Doutorado em Ciências Criminais) - Escola de Direito, Pontifícia Universidade Católica do Rio Grande do Sul, Rio Grande do Sul. 
A testemunha não só deve comparecer senão que deve declarar de forma efetiva sobre o fato, permitindo a plena cognitio do juiz e das partes, ademais de permitir identificar eventuais contradições entre as versões anterior e atual [...] $O$ ato de confirmar o anteriormente dito, sem efetivamente declarar, impede de alcançar os fins inerentes ao ato. A ratificação ou retificação deve ser aferida ao final, após a declaração integral, pelo confronto com a anterior ${ }^{32}$.

Portanto, tem-se que a mera ratificação - largamente utilizado no expediente forense - não se apresenta como instrumento hábil a conferir efetividade à repetição do ato de prova, devendo, assim, restringir-se àquelas hipóteses concernentes aos elementos irrepetíveis, observados, ainda, os precitados requisitos relativos à instauração do incidente de produção antecipada da prova, em atenção, portanto, às garantias que constituem o devido processo penal.

Finda esta parte de características gerais, tem-se que o encerramento do inquérito (ou seu arquivamento), se dá com a produção de relatório que informa tudo quanto apurado. Faz-se mister ressaltar que "não deve a autoridade policial esboçar juízo de valor no relatório, afinal, a opinião delitiva cabe ao titular da ação penal, e não ao delegado de polícia [...]". 33

Quanto à questão posterior ao encerramento do inquérito, é importante frisar a necessidade, não contemplada na legislação processual pátria, de exclusão física das peças de informação dos autos do processo, preservando apenas os atos de investigação tidos como irrepetíveis. ${ }^{34}$

Desta forma, os elementos irrepetíveis - as perícias por exemplo - e as cautelares ou antecipadas, mantêm a funcionalidade, motivo por que encontram, em certa medida, justificativa na incorporação dos autos. Esta razão não assiste aos demais elementos de informação colhidos ao longo do inquérito.

32 LOPES JUNIOR, Aury. Direito processual penal. $15^{\mathrm{a}}$ ed. São Paulo: Saraiva, 2018, p. 162, grifos nossos.

33 TÁVORA, Nestor; ALENCAR, Rosmar Rodrigues. Curso de direito processual penal. 13a . ed., Rev. Amp. e atual. Salvador: Juspodivm: 2018. p.179

34 GIACOMOLLI, Nereu José. A fase preliminar do processo penal: Crises, misérias e novas metodologias investigatórias. Edição. Rio de Janeiro: Lumen Juris, 2011. p. 116. 
Ademais, a cisão física dos volumes não seria, por si só, a salvação do sistema, visto que este se encontra permeado de muitos outros problemas. Porém, a adoção dessa separação, se devidamente realizada, em muito poderá ajudar, pelo menos na medida em que obrigará o titular da ação a jurisdicionalmente produzir as provas necessárias para a comprovação da imputação criminosa dirigida ao acusado, nomeadamente as repetíveis, não se servindo, com a largueza que hoje se encontra, da investigação para sustentar uma acusação ${ }^{35}$.

Não há como esperar o impossível, ou seja, a ausência de contaminação das peças do inquérito no processo penal e, mormente, nas decisões tomadas no decorrer e no fim do processo (sentença). No mínimo, o que foi colhido apresenta o risco de contaminação. Por isso, coadunando com o entendimento da problemática deste artigo, o corretivo há de perpassar pela, mas não se esgotar na, exclusão física do inquérito. ${ }^{36}$

Parece óbvia e simples a ideia de que para melhor conformar a persecução processual a um sistema acusatório, a exclusão dos elementos de informação seja a melhor direção para o cumprimento de garantias inerentes à próxima fase, do processo em si. Porém, não é o que ocorre costumeiramente, sendo, "ademais, a presença do inquérito no processo um dos fatores da hipertrofia desfigurante do modelo de processo penal do Estado de Direito". ${ }^{37}$

Tudo o que foi aludido até agora conflui para a ilação de que os elementos informativos, ou seja, os colhidos na fase investigativa, não podem e não devem servir como elementos de prova, colhidos sob o crivo de princípios básicos e primordiais do direito, como o contraditório e a ampla defesa. Resta demonstrado também os problemas de uma reforma parcial e pontual, como principal exemplo para esta pesquisa, a tímida mudança do art. 155 .

35 CHOUKR, Fauzi Hassan. Garantias constitucionais na investigação criminal. $3^{\mathrm{a}}$. ed. Rio de Janeiro: Lumen Juris, 2006. p. 136.

36 GIACOMOLLI, Nereu José. A fase preliminar do processo penal: Crises, misérias e novas metodologias investigatórias. Edição. Rio de Janeiro: Lumen Juris, 2011. p. 117. No mesmo sentido, cf. CHOUKR, Fauzi. Iniciação ao processo penal. Florianópolis: Empório do direito, 2017. p. 241.

37 GIACOMOLLI, Nereu José. A fase preliminar do processo penal: Crises, misérias e novas metodologias investigatórias. Edição. Rio de Janeiro: Lumen Juris, 2011. p. 117. 
Por todo o aduzido, razão assiste à Flaviane Barros, que menciona esse problema no sentido de que "a reforma parcial transformou o CPP em uma colcha de retalhos, mas não conseguiu retirar seu forte conteúdo autoritário e sua base inquisitorial" 38 .

\section{MAPEAMENTO dA INFLUÊNCIA dos ElEMENTOS DE INVESTIGAÇÃo PRELIMINAR NA FUNDAMENTAÇÃO DAS SENTENÇAS CRIMINAIS PUBLICADAS EM 2016 NO ESTADO DE ALAGOAS.}

\subsection{NotAs METOdológicas}

Conforme apontado no início deste trabalho, a problemática fundamental que justificou o desenvolvimento da análise presentemente exposta corresponde à constatação pragmática - sabida e criticada por diversos(as) autores(as) comprometidos(as) com a compatibilidade democrática-constitucional do processo penal brasileiro - de que parcela considerável das decisões judiciais definitivas prolatadas em âmbito criminal (sentenças criminais) utilizam-se, direta ou indiretamente, dos elementos de informação obtidos no curso das investigações preliminares. Objetivando avaliar o grau de utilização desses elementos informativos na fundamentação das sentenças criminais, empreendeu-se pesquisa de cariz empírico, cujo instrumental metodológico, bem como as dificuldades práticas e os resultados ao cabo obtidos, se pretende doravante compartilhar ${ }^{39}$.

38 BARROS, Flaviane de Barros. (Re)forma do Processo Penal: Comentários críticos dos artigos modificados pelas Leis n. 11.690/08 e n.11.900/09. $2^{\mathrm{a}}$. ed. Belo Horizonte: Del Rey, 2009, p. 3.

39 Convém salientar que pesquisa de semelhante teor - não obstante as distinções metodológicas que nortearam e fundamentaram o desenvolvimento e ulterior apresentação dos resultados obtidos - fora empreendida pelo jurista alemão Bernd Schünneman. Segundo o autor, cujo objeto heurístico correspondeu principalmente à análise do comportamento dos distintos atores processuais no curso da persecução, bem como na dinâmica por meio da qual esses atores se relacionavam com os elementos de informação obtidos no procedimento inquisitivo, "o conhecimento de autos da investigação preliminar tendencialmente incriminadores leva o juiz a condenar o acusado, ainda 
Em primeiro lugar, faz-se oportuno esclarecer que o recorte epistemológico sobre o qual recaíram as ferramentas heurísticas aqui mencionadas diz respeito às sentenças judiciais publicadas no ano de 2016, provenientes das Varas Criminais residuais do Estado de Alagoas. A delimitação temporal deste objeto se justificou pelo fato de que a execução do projeto se iniciou em 2017 , malgrado somente pôde ser concluída quase 02 (dois) anos depois, em razão da superveniência de variadas dificuldades empíricas que serão discutidas no segundo item deste tópico. Ademais, a escolha de decisões prolatadas no âmbito de Varas residuais (isto é, varas não concernentes a crimes dolosos contra vida, crimes relacionados a entorpecentes e crimes cometidos no contexto de violência doméstica) se deu pelo fato de existirem àqueles delitos, julgados em Varas Criminais Especializadas, relevantes distinções legais quanto ao procedimento de julgamento, o que poderia eventualmente comprometer a confiabilidade dos resultados encontrados. Por fim, o Estado de Alagoas foi escolhido em razão de ser o local na qual os pesquisadores residem e atuam profissionalmente.

Nesse sentido, foi obtida, por meio de ofício subscrito pela coordenação do Curso de Direito da instituição promovente do projeto ${ }^{40}$, no setor de Estatísticas do Tribunal de Justiça do Estado de Alagoas, uma listagem contendo 1464 processos criminais, relativos às sentenças publicadas no ano de 2016, subdivididas em 06 (seis) Varas Criminais da

que a audiência seja ambivalente, o que sugeriria uma absolvição". Com efeito, "o juiz tendencialmente apega-se à imagem do fato que lhe foi transmitida pelos autos da investigação preliminar; informações dissonantes desta imagem inicial não são apenas menosprezadas (...) mas frequentemente sequer percebidas (...) Por último, pode-se verificar que o juiz se orienta segundo a avaliação realizada pelo promotor, o que pode ser descrito por aquilo que quero chamar de efeito aliança”. Nesse sentido, cf. SCHUNEMANN, Bern. O juiz como um terceiro manipulado no processo penal? Uma confirmação empírica dos efeitos perseverança e aliança. In: GRECO, Luís. Estudos de direito penal, direito processual penal e filosofia do direito. São Paulo: Marcial Pons, 2013, p. 211 e 215.

SAMPAIO, André Rocha; RIBEIRO, Marcelo Herval Macêdo; ASSIZ, Amanda Ferreira. Relatório final de iniciação científica - Ciclo 2018/2019. Análise estatística da influência dos elementos de informação do inquérito policial na fundamentação da sentença penal condenatória nas varas criminais de Maceió. Maceió: Centro Universitário Tiradentes, junho de 2019. 
Capital (VCC), a saber: $10^{\mathrm{a}}$ VCC $12^{\mathrm{a}}$ VCC, $2^{\mathrm{a}}$ VCC, $3^{\mathrm{a}}$ VCC, $4^{\mathrm{a}}$ VCC e $6^{\mathrm{o}}$ VCC. Deste montante, convém pontuar que foram consideradas para fins de análise apenas as sentenças absolutórias e/ou condenatórias relativas a processos judiciais eletrônicos, sendo desprezadas, com efeito, as decisões extintivas de punibilidade e as decisões criminais prolatadas em processos físicos. Isso se justifica, em primeiro lugar, em razão da natureza das decisões de extinção de punibilidade, nomeadamente pelo fato de não se debruçarem sobre questões de mérito referentes ao caso criminal discutido; por outro lado, as decisões prolatadas no âmbito de processos físicos foram desconsideradas em virtude da dificuldade prática que se apresentaria quanto às suas análises, especialmente a necessidade de constante deslocamento ao Cartório das Varas Criminais correspondentes.

Além disso, levando-se em consideração o fato de que havia, por um lado, uma significativa quantidade de sentenças a serem analisadas e, por outro lado, dispunha-se de um número reduzido de pesquisadores, fez-se necessário valer-se de técnicas de amostragem com vistas à limitação no tamanho do universo populacional. Dessa forma, por intermédio de um cálculo amostral com índice de confiabilidade de $99 \%$ e margem de erro em $5 \%$, obteve-se a quantia final de 458 sentenças criminais a serem analisadas.

Para se proceder ao exame das referidas sentenças, foi elaborado um instrumental de pesquisa quantitativo-qualitativo, a partir do sistema de Formulários Google (Google Forms), contemplando 43 seções agrupadas estrategicamente. A primeira seção encerrava questionamentos propedêuticos, objetivando identificar o(a) pesquisador(a), o número do processo criminal em análise, a existência de prisão em flagrante, o sexo do réu ou da ré, o sexo da vítima, a natureza da sentença (se exclusivamente condenatória, exclusivamente absolutória, condenatória e absolutória - nos casos de multiplicidade de réus e/ou imputações - ou de absolvição sumária) e, finalmente, a existência ou não de utilização expressa do inquérito policial na fundamentação da sentença criminal. Caso a resposta ao último questionamento desta seção inicial fosse positiva, o(a) pesquisador(a) seria encaminhado à seção seguinte, na qual se objetivava averiguar a possibilidade de repetição, na fase instrutória-processual, do elemento informativo utilizado. Por outro lado, se a resposta fosse negativa, o(a) pesquisador(a) seria direcionado ao campo 
final de observações, na qual se apresentaria a oportunidade de registrar eventuais comentários importantes.

As seções seguintes (da terceira a quadragésima segunda seção) quedaram-se organizadas conforme a natureza do elemento informativo. Com efeito, o instrumento de análise contemplava praticamente todos os meios reconstitutivos de um caso penal frequentemente utilizados no curso da persecução, nomeadamente o depoimento testemunhal (seções 03 a 09), elementos documentais e/ou materiais (seção 10), exames periciais (seção 10), confissão (seções 11 a 16), reconhecimento de pessoas (seções 17 a 24), acareações (seções 25 a 30), interrogatório (seções 31 a 36) e depoimento da vítima (seções 37 a 42). Na quadragésima terceira e última seção, conforme já apontado, abria-se um campo genérico de observações, por meio da qual se apresentava ao (à) pesquisador (a) a possibilidade de registrar eventuais comentários relevantes.

Além dos questionamentos já mencionados, concernentes à utilização do inquérito e à repetibilidade do elemento informativo, o instrumento objetivava avaliar, uma vez constatada a utilização de um elemento inquisitorial na fundamentação da sentença, a) se este havia sido efetivamente reproduzido durante a fase processual, na presença da autoridade judicial; b) caso houvesse sido reproduzido, b.1) qual motivo levou o magistrado a dar preferência pela utilização do inquérito; b.2) se o conteúdo era absolutamente idêntico àquele produzido em sede policial ${ }^{41}$; c) nos casos em que inexistia reprodução do elemento informativo na fase processual, c.1) o que justificava esta situação;

41 O objetivo deste questionamento corresponde à necessidade de identificar se o ato de prova produzido na fase processual, perante o Juiz de Direito, diz respeito tão somente a uma mera ratificação do elemento informativo obtido durante as investigações preliminares. Com efeito, o que comumente se observa na práxis forenses é o fato de que muitas testemunhas, quando interpeladas pelo magistrado, na audiência de instrução, acerca dos eventos presenciados, conformam-se em dizer que "ratificam o depoimento prestado na delegacia de polícia”. Nesses casos, tem-se que a oralidade e a imediatidade, cânones fundamentais de um processo penal acusatório e democrático, acabam sendo violentamente escamoteadas, uma vez que o conteúdo daquele depoimento testemunhal termina sendo formado essencialmente pelas declarações prestadas ao condutor das investigações preliminares sem a observância, portanto, das garantias fundamentais constitutivas do devido processo legal. 
c.2) se a defesa estivera presente no momento em que o elemento foi consubstanciado durante o inquérito; d) se o elemento informativo decorria do depoimento de um agente policial militar; e) e, por fim, se as formalidades legais correspondentes à produção do ato haviam sido devidamente observadas.

A aplicação da ferramenta de pesquisa ao objeto delimitado perdurou por aproximadamente 06 (seis) meses e resultou, consoante planejamento inicial, no exame pormenorizado de 458 processos criminais. As conclusões obtidas a partir dessa análise serão detalhadamente compartilhadas no terceiro item deste tópico. Neste momento, contudo, afigura-se relevante discutir a respeito de algumas dificuldades empíricas que perpassaram o desenvolvimento da pesquisa em comento.

\subsection{DiFICULDADES EMPÍRICAS}

Conforme mencionado no preâmbulo deste tópico, a execução do projeto principiou ao cabo de 2017 , mais especificamente em outubro daquele ano. Num primeiro momento, os participantes se detiveram na elaboração de um instrumental investigativo que permitisse avaliar - qualitativa e quantitativamente - a utilização do inquérito policial na fundamentação das sentenças criminais. A dificuldade inicialmente observada concerniu ao fato de que, à medida em que as análises eram feitas, se fazia necessário proceder a frequentes ajustes no formulário de pesquisa, uma vez que novas e imprevisíveis demandas surgiam a partir do desvelamento de particularidades observadas em determinados casos concretos. Nesse sentido, paralelamente à realização de ajustes no formulário, fazia-se por consequente necessário retomar todos os processos já analisados em momento anterior, haja vista que a ausência deste procedimento poderia importar na existência de respostas distintas relativamente à mesma situação fática.

Após superada a fase inicial de elaboração do questionário - que perdurou, não obstante os ulteriores ajustes realizados, aproximadamente 4 meses - passou-se à fase seguinte de coleta de dados. Neste ponto residem seguramente as maiores dificuldades. Com efeito, em meados de 2018 os pesquisadores se encaminharam às Varas Criminais supracitadas, 
objetivando angariar a listagem de processos julgados no ano de 2016. De imediato, pôde-se constatar uma notável resistência dos servidores dos cartórios ao atendimento daquela solicitação, inicialmente apresentada de maneira informal. Enquanto em algumas Varas se alegava a impossibilidade de fornecimento da listagem requerida em virtude da necessidade de apresentação de documento formal (ofício extrajudicial), noutras Varas se informava que seria preciso retornar no mês seguinte, em razão do cartório estar passando por correições internas, o que obstaculizaria o fornecimento dos dados requeridos.

No entanto, é importante pontuar que, mesmo sendo respeitadas as observações contrapostas pelos servidores dos cartórios, as dificuldades à obtenção dos processos julgados subsistiram. Em uma das Varas nas quais se alegava existir correição interna, por exemplo, o servidor que prestou atendimento informou que o funcionário responsável por aquela atividade (gerenciamento estatístico) estava em período de férias e que somente seria possível atender à solicitação no mês seguinte. Noutro caso em que foi exigida a apresentação de ofício, conquanto este tenha sido devidamente emitido e assinado pela coordenação do curso de direito da instituição de ensino vinculada à pesquisa, foram disponibilizados aos pesquisadores dados controversos e carentes de padronização.

De fato, fora possível chegar-se a esta conclusão a partir da verificação de divergências no que concerne à quantidade de processos disponibilizados - enquanto uma Vara havia fornecido listagem contendo 197 processos sentenciados em 2016, outra Vara forneceu uma relação com apenas 16 processos julgados naquele ano -, levantando suspeitas de que os filtros utilizados para a obtenção dos dados pudessem estar equivocados, situação que foi posteriormente confirmada pelo Chefe do Setor de Estatísticas do Tribunal de Justiça do Estado de Alagoas. Com efeito, foi apenas naquele órgão que se verificou ser possível obter a relação de processos necessária ao início das análises. Dessa forma, levando-se em conta a impossibilidade de coligir informações mais fidedignas do que aquelas fornecidas pelo referido setor, as análises puderam ser efetivamente inauguradas, fato que sucedeu em fevereiro de 2019 - quase 6 meses após o início das tentativas de obtenção dos dados. 


\subsection{Resultados OBTIDOS}

Considerando aqui a extensa quantidade de resultados obtidos, pretende-se compartilhar apenas aqueles que mais se aproximem da problemática de pesquisa exposta nos tópicos iniciais. Nesse sentido, tem-se que o primeiro resultado alcançado, correspondente à presença do auto de prisão em flagrante nos processos julgados nas Varas Criminais residuais de Maceió, apresentou-se, já de imediato, bastante alarmante: em 87,8\% dos casos - o equivalente a 402 processos - a persecução criminal havia se iniciado a partir da prisão em flagrante do suposto autor do delito.

Quanto à natureza das sentenças penais prolatadas nos processos, verificou-se que cerca de $72 \%$ (332) eram exclusivamente condenatórias; $16 \%$ (72) exclusivamente absolutórias; 11\% (51) absolutórias e condenatórias e, por fim, apenas cerca de 01\% (03) das sentenças eram de absolvição sumária. Curioso notar que em parcela significativa das sentenças penais exclusivamente absolutórias (68\%), a persecução havia sido inaugurada a partir da formalização de um auto de prisão em flagrante, não obstante o desfecho do processo houvesse sido o afastamento da pretensão acusatória e conseguinte absolvição do réu.

Relativamente ao questionamento que pode ser compreendido como o mais importante deste trabalho, os dados obtidos não apenas ratificaram a hipótese inicialmente ventilada - de que um percentual superior a $90 \%$ das sentenças condenatórias se utilizava, direta ou indiretamente, dos elementos informativos oriundos do inquérito policial - como sinalizaram uma conjuntura ainda mais preocupante: em 80,6\% dos casos, o que corresponde a 369 processos, o magistrado se utilizou expressamente de algum elemento informativo produzido durante as investigações preliminares. Desse total, cerca de 91\% (336) dos processos diziam respeito a sentenças condenatórias (incluídas aqui as sentenças exclusiva ou parcialmente condenatórias - 289 e 47, respectivamente), nas quais houve explícita menção a algum elemento inquisitorial produzido sem a observância das garantias inerentes ao processo.

Em primeiro lugar, é preciso esclarecer que o montante acima mencionado compreende apenas as hipóteses nas quais o magistrado mencionou de maneira expressa e particularizada a existência de algum elemento informativo oriundo da fase preliminar. Isso significa que 
não estão contabilizados os casos nas quais o magistrado procedeu a referências genéricas ao inquérito ou, alternativamente, não identificou com precisão o local de onde o elemento informativo foi extraído ${ }^{42}$. Por essas razões é que se aponta a superação da expectativa inicialmente aventada: enquanto se hipotetizava encontrar, de início, aproximadamente $90 \%$ dos processos utilizando explícita ou implicitamente algum elemento informativo pré-processual, encontrou-se um percentual acima de 90\% correspondente apenas à utilização explícita, não sendo incluídos na contagem aqueles casos nos quais se constata apropriações indiretas das informações coligidas no caderno inquisitorial. Ainda nesse ponto, teve-se que cerca de $61 \%$ (226) dos elementos informativos poderiam ter sido repetidos no curso do processo, enquanto aproximadamente $38 \%$ correspondiam a elementos irrepetíveis.

Quanto à prova testemunhal, constatou-se que em 83,5\% (308) das sentenças o depoimento da testemunha fora extraído da fase probatória (audiência de instrução), ao passo que em 5,7\% dos casos - 21 sentenças - o depoimento havia sido extraído do inquérito policial. Nos demais casos (10,8\% ou 40 processos), não se verificou utilização de elementos testemunhais. Oportuno destacar que nas hipóteses em que o magistrado se utilizava dos depoimentos extraídos das investigações preliminares, em 66,7\% não houve repetição do depoimento na fase instrutória, sendo a inviabilidade de localização da testemunha a principal razão $(53,8 \%)$ a justificar aquele cenário. Ademais, nos casos em que se constatou a utilização

42 De fato, foi possível observar em diversas sentenças a existência de comentários abstratos acerca do inquérito policial - como, por exemplo, em um caso em que o julgador afirma que "a materialidade do delito de roubo [...] ficou evidenciada, uma vez que as provas testemunhais ratificadas em juízo, somadas àquelas produzidas na fase inquisitorial, são suficientes à constatação da ocorrência do referido crime" (grifos nossos). Neste caso, considerando que não houve rigorosa individualização quanto ao elemento informativo por meio da qual se permitiu consubstanciar àquele convencimento relativo à materialidade delitiva, o processo não foi contabilizado a título de utilização expressa do inquérito. Doutra banda, não raras vezes se percebia nas sentenças judiciais menções nas quais não se quedava possível identificar o exato local em que o conteúdo pretensamente probatório restou extraído, como numa das Varas Criminais, cujas sentenças com habitualidade se resignavam a colacionar o teor do depoimento das testemunhas, sem identificar se aquele depoimento fora extraído da fase pré-processual ou processual. Nesses casos, igualmente o processo não restava contabilizado para fins de utilização expressa. 
de um testemunho obtido na fase preliminar, em 100\% dos casos a defesa não se fizera presente no momento da colheita do depoimento.

Finalmente, faz-se mister salientar que, a despeito de ter sido aprioristicamente planejada a análise quanto à identidade entre o depoimento testemunhal colhido na fase processual em relação àquele obtido no curso das investigações preliminares, o exame das mídias digitais concernentes às audiências de instrução restou inviabilizado. Isso se deu em virtude das já comentadas dificuldades empíricas que sobrevieram durante a execução do projeto, especialmente a necessidade de proceder a constantes reajustes no formulário de pesquisa e conseguinte reanálises nos processos. Sendo assim, não se verificou possível examinar de maneira mais percuciente a existência de meras ratificações nos depoimentos testemunhais, não obstante tenha sido possível constatar, em pelo menos 10 processos, a absoluta identidade entre o conteúdo dos testemunhos colhidos em juízo relativamente àqueles oriundos do inquérito policial ${ }^{43}$.

\section{A CRIPTOMOTIVAÇÃo A SERVIÇO DE VALORES AUTORITÁRIOS}

Que o modelo processual penal brasileiro possui uma matriz autoritária não é nenhuma novidade. Para além das óbvias influências do Codice Rocco em nosso vigente Código de Processo Penal ${ }^{44}$ (apesar das reformas de 2018 que, como bem salienta Jacinto Coutinho, foram puramente superficiais) ${ }^{45}$, é realmente no campo da law in action que

43 Em um desses processos, por exemplo, o magistrado se resignou a mencionar na fundamentação da sentença que "os Policiais Militares ouvidos em juízo ratificaram o depoimento prestado na fase policial” (in verbis). Noutro caso, a testemunha de acusação, também policial militar, cujo depoimento foi transcrito na fundamentação da sentença, afirmou "que se recorda da situação; que reconhece como sua a assinatura do depoimento prestado perante a autoridade policial; que ratifica inteiramente o depoimento prestado perante a autoridade policial" (in verbis).

44 Para mais detalhes, cf. GLOECKNER, Ricardo. Autoritarismo e processo penal: uma genealogia das ideias autoritárias no processo penal brasileiro, vol. I. Florianópolis: Tirant lo Blanch, 2018.

45 COUTINHO, Jacinto Nelson de Miranda. Observações sobre os sistemas processuais penais. Curitiba: Observatório da mentalidade inquisitória, 2018. p. 261 e ss. 
percebemos o maquinar de uma cultura inquisitorial capaz de perverter qualquer inovação de aparente cariz acusatório.

As questões relacionadas à utilização dos elementos de informação do fascículo de investigação preliminar para a fundamentação de uma eventual condenação criminal é, nesse caldo autoritário, o que poderíamos chamar de "sintoma", no sentido psicanalítico do termo. O que se pretende dizer aqui é que o autoritarismo que impregna a mecânica da utilização do inquérito pelo juiz é da ordem do desejo em vias de satisfação, mas desde uma perspectiva paradoxal, visto se tratar de certa "satisfação às avessas". ${ }^{46}$

O sintoma opera aqui como um recalcamento, é uma espécie de traço fenomenal de algum submerso que per si, em um primeiro momento, apresenta-se como um "sem-sentido, uma opacidade no discurso do sujeito, por representar alguma irrupção de verdade" ${ }^{47}$. Por meio de sua análise torna-se possível ler certo "traço apagado", que emerge, desde a ótica lacaniana, na linguagem e "que apreende o desejo inconsciente e que abriga inadvertidamente um sentido - o do conflito recalcado determinando a maneira pela qual o discurso do sujeito se organiza"48.

Assim, somente analisando os bolsões de linguagem que parecem se situar despropositadamente nas brechas do discurso padrão da decisão condenatória é que é possível tentar algum processo de desvelamento do registro autoritário que se instala entre um e outro enfraquecer de garantias constitucionais para dar vazão a discursos securitários e emergenciais.

No que tange especificamente às questões ligadas ao presente artigo, podemos ver como se opera tal degenerescência ao autoritarismo nas já referidas Reformas de 2008 e sua tentativa fracassada de adequação a um sistema acusatório. Na contramão dos fluxos políticos do processo penal democrático nos chamados países centrais, que há décadas empregaram medidas para evitar a utilização plena do inquérito policial pelo juiz da fase processual, as discussões que figuravam no parlamento no

46 DIAS, Maria das Graças Leite Vilela. O sintoma: de Freud a Lacan. Psicologia em Estudo, Maringá, v. 11, n. 2, p. 399-405, mai./ago. 2006.

47 Idem.

48 Idem. 
curso das reformas envolviam defensores de sua utilização exclusiva até mesmo para condenar o réu ${ }^{49}$.

Em uma espécie de "pseudosolução salomônica", nem vingou a proposta original, de impedimento do uso dos elementos informativos para fundamentar a sentença $a^{50}$, e nem a proposta alternativa que envolvia seu acesso ilimitado, irrompeu-se assim sua redação atual, que possibilita que o juiz use, mas não exclusivamente, os atos investigativos em sua fundamentação.

Ocorre que, diante da mentalidade inquisitória instaurada nas engrenagens da máquina processual penal tupiniquim, impedir meramente uma fundamentação exclusiva com base no fascículo inquisitorial é cinicamente menosprezar o potencial perversor do sistema de justiça criminal nacional; é a verdadeira construção de veios de contaminação que possibilitam a utilização de $99,9 \%$ do que fora colhido inquisitorialmente, legitimados por eventuais $0,1 \%$ de provas, no sentido forte do termo, ou seja, elementos produzidos em contraditório judicial.

Para além disso, nada impede que até mesmo a diminuta fração de provas utilizada na fundamentação seja composta a partir de estratégias antidemocráticas, como a mera ratificação de depoimentos da fase inquisitorial, que, de acordo com a pesquisa ora apresentada, em praticamente $100 \%$ das vezes foram obtidos na ausência de qualquer defensor, ou o fornecimento de informações pela voz pública, constituindo o que o direito alienígena tanto combate sob a alcunha de "hearsay testimony" 51.

Precisamos destacar, a bem da verdade, que os dados aqui publicados não revelam nenhuma ilegalidade crassa; o que a presente pesquisa tencionara demonstrar é a estreita dependência que nosso sistema de justiça tem dos elementos informativos oriundos do inquérito policial, ao passo que buscamos, no tópico em andamento, suscitar novas hipóteses de pesquisa a partir dos dados apresentados.

49 Como no caso da proposta encaminhada pela Associação Nacional dos Procuradores da República.

50 As exceções já eram as provas cautelares, irrepetíveis e antecipadas (art. 155).

51 Para mais informações, Cf. MALAN, Diogo Rudge. O direito ao confronto no processo penal. Rio de Janeiro: Lumen Juris, 2009. 
Um segundo e importante alerta precisa ser dito inicialmente: é impossível detectarmos se os elementos informativos utilizados foram ou não o motivo principal da condenação, até por se tratar de questão de ordem psíquica, presente na blackbox da psique judicial, logo insuscetível de análise, o que não quer dizer que o número de $80,6 \%$ de sentenças que se valeram expressamente de algum elemento do fascículo inquisitório - 91\% das condenatórias - não tenha qualquer significado relevante.

A utilização de elementos de informação da fase investigativa é amplamente atacada pela defesa, sobretudo quando se tratam de atos repetíveis que ou não foram repetidos ou o juiz apenas optou por se valer do elemento de informação presente na fase preliminar; assim sendo, a fundamentação condenatória estaria imune a esse tipo de ataque caso tivesse se valido apenas de provas, logo produzidas em contraditório judicial.

Claro que não podemos descartar a possibilidade de o magistrado ter de fato se convencido com base em provas, exclusivamente, e ter lançado mão de convocar para a fundamentação elementos investigativos apenas para demonstrar um teor maior de evidências contra o condenando, ainda que assumindo o risco de ter a decisão atacada em via recursal. Ademais, é importante destacar que os tribunais têm a forte tendência de não aceitar os argumentos de reforma com base em utilização de elementos informativos, quando corroborados por (qualquer) ato de prova.

Não obstante, o fato de $91 \%$ das sentenças condenatórias terem se valido expressamente de elementos da fase inquisitorial denota certa insegurança motivacional, caso se valesse o juiz exclusivamente de elementos de prova, além de ser improvável que mediante número tão expressivo de sentenças, oriundas de varas diversas, seu motor tenha sido apenas fortalecer uma fundamentação já eventualmente suficientemente baseada nas provas produzidas em contraditório.

Ou seja, ainda que impossível, nessa altura da pesquisa, precisar quais decisões eram dependentes ou não dos elementos de informação para a condenação, se apenas 1\% delas assim o fosse já estaria comprovada a nódoa inquisitorial escoando o princípio acusatório para fora do modelo processual penal brasileiro.

Ademais, é importante frisar que do total de elementos de informação referidos na fundamentação das sentenças pesquisadas, cerca 
de $61 \%$ se enquadravam nos chamados "atos de investigação repetíveis", ou seja, em mais da metade das vezes mesmo havendo possibilidade, em tese, de repetição do ato em contraditório judicial público, o magistrado fez a opção por se valer do que fora colhido unilateralmente pela polícia sob a égide do sigilo investigativo, em uma situação de absoluta ausência de defesa ${ }^{52}$.

Tal dado, de 61\% de atos repetíveis, enfraquece a hipótese de o juiz estar apenas incrementando uma argumentação já suficientemente embasada em provas (no sentido forte do termo); se seu conjunto de provas possui certas peças dissonantes com o que foi colhido na fase inquisitorial, utilizar-se destes últimos elementos escancara uma opção manifesta pelo inquisitório, em detrimento de valores democráticos.

Finalizando, enfim, a dissecação analítica que antecede o gotejar de novas hipóteses, o dado de $87,8 \%$ de processos cuja persecução teve como estopim uma prisão em flagrante delito é emblemático para revelar a enorme dependência que temos do policiamento ostensivo - por sua vez bastante deficitário, por uma série de motivos que não cabem nos estreitos limites deste trabalho - e a fraquíssima capacidade de investigação da polícia judiciária quando provocada por notitia criminis de outras naturezas diversas da coercitiva (apenas 12,2\% dos processos tiveram inquéritos iniciados desta forma).

Insta salientar, todavia, que, apesar do percentual baixo de absolvições, em seu conjunto próprio cerca de $68 \%$ delas também carreavam inquéritos policiais que se originaram com uma prisão em flagrante delito, o que, por sua vez, amplia nosso leque de análise, demonstrando como não apenas somos hiperdependentes do flagrante como também este é mal realizado, colocando em xeque a própria qualidade dos que foram usados de base para suas respectivas condenações, sobretudo quando o contraditório possível nesses casos é o chamado "contraditório diferido".

52 Na maioria das vezes o magistrado se valeu de atos provenientes do inquérito policial ainda que dotados de repetibilidade sem sequer justificar a preferência pelos elementos colhidos em sede investigativa. Nas oportunidades em que justificou, a impossibilidade de encontrar testemunha ou réu foi um dos argumentos principais pela preferência, ainda que de difícil comprovação empírica. 
O que se percebe, em última análise, é um esforço de expulsão do contraditório dos elementos epistêmicos à disposição para o julgamento, reduzindo demasiadamente sua efetiva participação a uma mera fiscalização acerca da legalidade visível sobre atos já documentados, em um alheamento total do confronto da prova ${ }^{53}$.

Se conciliarmos tal sintoma com a dependência a flagrantes e, consequentemente, a depoimentos de policiais, há um inexorável deslocamento do epicentro do processo para a fase preliminar, policial, perfazendo o que Foucault já denunciava como sendo uma "submissão da justiça à polícia" ${ }^{54}$. Não colocaríamos propriamente em termos de submissão - o que atribuímos ao estilo denunciativo foucaultiano - mas de parasitismo epistêmico.

Vale, por fim, salientar que uma das dificuldades mais pungentes da pesquisa foi a rala fundamentação judicial das condenações no que tange às provas. Na grande maioria das vezes, em decisões cuja estrutura básica se repete à exaustão, o magistrado se utiliza do que Taruffo chama de "modelo holístico de fundamentação”, em contraponto ao modelo analítico ${ }^{55}$.

Desde essa perspectiva, há, igualmente, uma degeneração dos próprios efeitos democráticos do livre convencimento motivado, sustentáculo de defesa contra arbítrios judiciais, transformando nosso sistema decisório em uma espécie de íntima convicção criptografada.

O que se tem, em suma, é uma verdade autoritária erigida a status de verdade estatal oficial, calcada no enfraquecimento máximo do contraditório, na hiperdependência do que fora produzido (precariamente)

53 Não é exclusividade brasileira a percepção autoritária de que o contraditório, menos que um método de (re)produção da verdade, seria um obstáculo a esta. Ferrua demonstra como o próprio sistema italiano, a quem somos profundos tributários, tem sofrido duros golpes inquisitórios de tentativa de afastamento do contraditório pleno na epistemologia da prova, desconsiderando seu valor epistêmico como método e o encarando como simples instrumento de resolução de uma lide. (FERRUA, Paolo. Gênese da reforma constitucional do "giusto processo" na Itália. Revista Brasileira de Direito Processual Penal, Porto Alegre, vol. 3, n. 2, p. 661-688, mai.-ago. 2017)

CASTRO, Françoise. Foucault par luimême, 2003. Disponível em <https:// www.youtube.com/watch?v=Xkn31sjh4To> 
pela polícia e na íntima convicção criptomotivada, redundando em algo pior do que se filiar a um modelo inquisitório, apresentar-se epidermicamente acusatório, quando o romper de sua fina casca faz erigir a matriz inquisitória que pulsa em suas entranhas.

\section{Considerações Finais}

O inquérito policial possui uma evidente função democrática dentro da persecução criminal, qual seja, a de evitar que ao provável inocente seja imposto o status de réu em um processo penal, filtrando, indiretamente, as acusações aventureiras e levianas. Em que pese haver extratos da doutrina jurídica que defendam sua extinção, entendemos se tratar de peça importante para o exercício de direitos e garantias fundamentais, quando devidamente conduzido e controlado.

Não obstante, o que se percebe na maioria das vezes são inquéritos policiais de baixíssimo teor epistêmico, seja em virtude da precariedade estrutural, da formação deficitária do agente de polícia, da baixa remuneração ou até mesmo de certa cultura policial entranhada no agir desta instituição. Porém, apesar de tais fatores, legitimados pelo artigo 155 do Código de Processo Penal, os magistrados costumam se valer amplamente dos elementos de informação contidos em seu fascículo, ainda que colhidos ao alvedrio do contraditório, da ampla defesa e da publicidade dos atos.

A presente pesquisa teve o escopo de investigar a intensidade da utilização dos elementos informativos dos atos de investigação na sentença penal e percebeu um número de $80,6 \%$ de sentenças que se valeram expressamente de algum elemento do fascículo inquisitório, 91\% das condenatórias, mesmo sendo $62 \%$ desses atos passíveis de repetição.

O teor antidemocrático dos dados colhidos se evidenciam quando se constata que em $100 \%$ dos casos a defesa não estava presente no momento da colheita da informação pela polícia, resultando na conclusão de que na grande maioria das vezes os réus em um processo penal no Brasil são condenados, em última análise, com base em atos privados do contraditório judicial.

Entre as dificuldades da pesquisa em questão esteve a opacidade inerente ao motivar judicial tupiniquim, lançando mão de termos vagos e 
expressões generalistas que impedem o analista de conseguir escrutinar devidamente os elementos de convencimento de forma mais palpável.

Trata-se, todavia, de cultura com total guarida nos tribunais superiores - extremamente flexíveis no que tange à robustez da fundamentação de decisões penais -, conformando um cenário de ampla possibilidade de utilização de elementos inquisitoriais provenientes do inquérito policial cuja fiscalização é ofuscada por uma cultura de criptomotivação decisional que, ao cabo, impede o debruçar de olhares atentos ao funcionamento de um devido processo penal pautado em valores democráticos.

O recente advento da Lei 13.964/19 traz a esperança de um respiro democrático para o processo penal. Como não acreditamos em soluções meramente legalistas, é necessário aguardar como sua aplicabilidade se conformará, o que dependerá de um vasto número de fatores ainda impossíveis de serem antecipados.

\section{REFERÊNCIAS}

BARROS, Flaviane de Barros. (Re)forma do Processo Penal: Comentários críticos dos artigos modificados pelas Leis n. 11.690/08 e n.11.900/09. 2a ed. Belo Horizonte: Del Rey, 2009.

CASTRO, Françoise. Foucault par luimême, 2003. Disponível em <https://www. youtube.com/watch?v=Xkn31sjh4To>. Acesso em 26 jan. 2020.

CHOUKR, Fauzi Hassan. Garantias constitucionais na investigação criminal. $3^{\mathrm{a}}$. ed. Rio de Janeiro: Lumen Juris, 2006.

CHOUKR, Fauzi Hassan. Iniciação ao processo penal. Florianópolis: Empório do direito, 2017.

COUTINHO, Jacinto Nelson de Miranda. Observações sobre os sistemas processuais penais. Curitiba: Observatório da mentalidade inquisitória, 2018.

DIAS, Maria das Graças Leite Vilela. O sintoma: de Freud a Lacan. Psicologia em Estudo, Maringá, v. 11, n. 2, p. 399-405, mai./ago. 2006.

DUCLERC, Elmir. Direito Processual Penal. Rio de Janeiro: Lumen Juris, 2007.

FERNANDES, Antonio Scarance. Teoria Geral do Procedimento e O Procedimento no Processo Penal. São Paulo: RT, 2005. 
FERRUA, Paolo. Gênese da reforma constitucional do "giusto processo" na Itália. Revista Brasileira de Direito Processual Penal, Porto Alegre, vol. 3, n. 2, p. 661-688, mai.-ago. 2017. http://dx.doi.org/10.22197/rbdpp.v3i2.61

GIACOMOLLI, Nereu José. A fase preliminar do processo penal: Crises, misérias e novas metodologias investigatórias. Edição. Rio de Janeiro: Lumen Juris, 2011.

GLOECKNER, Ricardo. Autoritarismo e processo penal: uma genealogia das ideias autoritárias no processo penal brasileiro, vol. I. Florianópolis: TirantloBlanch, 2018.

LOPES JR., Aury. GLOECKNER, Ricardo Jacobsen. Investigação Preliminar no Processo Penal. ed. 5. São Paulo: Saraiva, 2013.

LOPES JUNIOR, Aury. Direito processual penal. 15ª ed. São Paulo: Saraiva, 2018.

MALAN, Diogo Rudge. O direito ao confronto no processo penal. Rio de Janeiro: Lumen Juris, 2009.

NICOLITT, André. Manual de processo penal. 8. ed. Belo Horizente: D”plácido, 2019.

RAMOS, Silvia; MUSUMECI, Leonarda. "Elemento suspeito”. Abordagem policial e discriminação na cidade do Rio de Janeiro. Boletim Segurança e Cidadania, n. 8 , novembro de 2004 .

SAMPAIO, André Rocha. A onipresença processual dos atos de investigação como sintoma biopolítico. Tese (Doutorado em Ciências Criminais) - Escola de Direito, Pontifícia Universidade Católica do Rio Grande do Sul. Porto Alegre, 2015.

SCHUNEMANN, Bern. O juiz como um terceiro manipulado no processo penal? Uma confirmação empírica dos efeitos perseverança e aliança. In: GRECO, Luís. Estudos de direito penal, direito processual penal e filosofia do direito. São Paulo: Marcial Pons, 2013.

TARUFFO, Michele. Ermeneutica, prova e decisione. Rev. Bras. de Direito Processual Penal, Porto Alegre, vol. 4, n. 1, p. 129-148, jan.-abr. 2018.

TÁVORA, Nestor; ALENCAR, Rosmar Rodrigues. Curso de direito processual penal. $13^{\mathrm{a}}$. ed., Rev. Amp. e atual. Salvador: Juspodivm, 2018.

VASCONCELLOS, Vinicius Gomes de. Fundamento e função do processo penal: a centralidade do juízo oral e sua relação com as demais fases da persecução penal para a limitação do poder punitivo. Revista Eletrônica de Direito Processual - REDP, Rio de Janeiro, v. 19, n. 2, p. 229-260, ago./2018. https://doi.org/10.12957/ redp.2018.31959 


\section{Informações adicionais e declarações dos autores (integridade científica)}

Declaração de conflito de interesses (conflict of interest declaration): os autores confirmam que não há conflitos de interesse na realização das pesquisas expostas e na redação deste artigo.

Declaração de autoria e especificação das contribuições (declaration of authorship): todas e somente as pessoas que atendem os requisitos de autoria deste artigo estão listadas como autores; todos os coautores se responsabilizam integralmente por este trabalho em sua totalidade.

- Marcelo Herval Macêdo Ribeiro: projeto e esboço inicial (conceptualization), desenvolvimento da metodologia (methodology), coleta e análise de dados (data curation), levantamento bibliográfico (investigation), revisão bibliográfica (investigation), redação (writing - original draft), participação ativa nas discussões dos resultados (validation), revisão crítica com contribuições substanciais (writing - review and editing), aprovação da versão final.

- André Rocha Sampaio: projeto e esboço inicial (conceptualization), desenvolvimento da metodologia (methodology), coleta e análise de dados (data curation), levantamento bibliográfico (investigation), revisão bibliográfica (investigation), redação (writing - original draft), participação ativa nas discussões dos resultados (validation), revisão crítica com contribuições substanciais (writing - review and editing), aprovação da versão final.

- Amanda Assis Ferreira: projeto e esboço inicial (conceptualization), desenvolvimento da metodologia (methodology), coleta e análise de dados (data curation), levantamento bibliográfico (investigation), revisão bibliográfica (investigation), redação (writing - original draft), participação ativa nas discussões dos resultados (validation), revisão crítica com contribuições substanciais (writing - review and editing), aprovação da versão final. 
Declaração de ineditismo e originalidade (declaration of originality): os autores asseguram que o texto aqui publicado não foi divulgado anteriormente em outro meio e que futura republicação somente se realizará com a indicação expressa da referência desta publicação original; também atestam que não há plágio de terceiros ou autoplágio.

Dados do processo editorial (http://www.ibraspp.com.br/revista/index.php/RBDPP/about/editorialPolicies)

- Recebido em: 20/11/2019 Equipe editorial envolvida

- Controle preliminar e verificação de plágio: 10/12/2019

- Avaliação 1: 15/12/2019

- Editor-chefe: 1 (VGV)

- Editora-associada: 1 (MSG)

- Avaliação 2:17/12/2019

- Revisores: 3

- Avaliação 3: 26/12/2019

- Decisão editorial preliminar: 26/12/2019

- Retorno rodada de correções: $26 / 01 / 2020$

- Decisão editorial final: $16 / 02 / 2020$ 


\section{COMO CITAR ESTE ARTIGO:}

RIBEIRO, Marcelo H. M.; SAMPAIO, André R.; FERREIRA, Amanda A. A influência dos elementos de informação do inquérito policial na fundamentação da sentença penal condenatória: uma análise das sentenças prolatadas pelas varas criminais de Maceió/AL. Revista Brasileira de Direito Processual Penal, Porto Alegre, vol. 6, n. 1, p. 175-210, jan./abr. 2020. https://doi.org/10.22197/rbdpp.v6i1.299

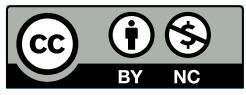

Esta obra está licenciada com uma Licença Creative Commons Atribuição-NãoComercial 4.0 Internacional. 